\title{
Diet of autochthonous populations in Yakutia using isotopic, ethnographic, historical and archaeological data
}

\author{
Liubomira Romanova ${ }^{1,2, *}$, Vincent Balter ${ }^{3}$, Laurent Simon ${ }^{4}$, Patrice Gerard ${ }^{1}$, Nadejda \\ Pokatilova $^{5}$, Eric Crubezy ${ }^{1}$
}

1 Molecular Anthropology and Image Synthesis Laboratory, UMR 5288, Toulouse Paul Sabatier University, 37 allées Jules Guesdes, 31000, Toulouse, France

2 North-Eastern Federal University, 56 Belinskogo street, 677000, Yakutsk, Russia, liubomiraromanova@gmail.com (corresponding author)

${ }^{3}$ CNRS, ENS de Lyon, Université Claude Bernard Lyon 1, UMR 5276 LGLTPE. 46, Allée d'Italie, 69342, Lyon, France

${ }^{4}$ Université Claude Bernard Lyon 1, CNRS, ENTPE, UMR5023 LEHNA, F-69622, Villeurbanne, France

${ }^{5}$ Institute for Humanities Research and Indigenous Studies of the North, Russian Academy of Science, Siberian Branch, 1 Petrovskogo street, 677000, Yakutsk, Russia

\begin{abstract}
This article investigates, for the first time, the diet of the Yakut population between the 15th and 19th centuries AD. Analyses of the stable isotopes of carbon and nitrogen in human and animal bone collagen were used for the study. The stable isotope values were then compared through four historical periods, three geographical areas, sexes, and socio-economic groups determined by the presence or absence of artefacts in the excavated tombs. The results highlight the variety of dietary practices among the Yakuts. There are significant differences between the North, characterised mostly by the consumption of herbivores, the Viluy region, where fish had an important role, and Central Yakutia with a diversified diet. No differences were seen between the diets of men and women. The group of elites had a stable diet based on meat and milk consumption. Samples before $1700 \mathrm{AD}$ had $\delta 15 \mathrm{~N}$ values that were higher than samples from other periods, probably due to greater consumption of fish and foal meat. These data were compared with ethnographic, historical and archaeological information so as to better depict the diet of these past populations.
\end{abstract}

\section{Keywords}

Carbon isotopes, nitrogen isotopes, Yakutia, Eastern Siberia, diet, 15th-19th centuries AD 


\section{Introduction}

Today, archaeology uses a wide array of biological analyses to investigate the lifestyles of ancient populations. Stable isotope analyses are routinely applied for the reconstruction of past population dietary habits. Paleodietary studies using carbon and nitrogen stable isotope analyses have been conducted on populations of Siberia, in the Cis- Baikal region including the Upper Lena river (Katzenberg and Weber, 1999; Katzenberg et al., 2009, 2012; Weber et al., 2011), Southern Siberia (Murphy et al., 2013), Western Siberia (Marchenko, 2015), the Baraba forest steppe (Privat et al., 2005; Molodin et al., 2015), the Minusinsk Basin (Svyatko et al., 2013; Svyatko, 2014), and the Altai Mountains (O'Connell et al., 2003). There is however a lack of studies focusing on East Siberia, where such analyses have a potentially large field of application, due to different ecological niches and a traditional way of life that has sometimes lasted until today.

Diet reconstruction with stable isotopes is implied in the sentence "We are what we eat". In other words, there is a direct relationship between the isotopic composition of the diet and consumer tissues. For carbon isotopes, a trophic level enrichment from diet to consumer is approximately 1\%o, while for nitrogen isotopes it is 3 to 6\%o (De Niro and Epstein, 1981; Schoeninger and De Niro, 1984; Bocherens and Drucker, 2003; Hedges and Reynard, 2007; O'Connell et al., 2012). The carbon isotope value $(\delta 13 \mathrm{C})$ gives information about the distinction of diet based on $\mathrm{C} 3$ or $\mathrm{C} 4$ photosynthetic plant pathways as well as marine food resources. Freshwater sources however, have a significant variability in $\delta 13 \mathrm{C}$ values (Katzenberg and Weber, 1999; Katzenberg et al., 2012; Katzenberg and Waters-Rist, 2018). In addition to $\delta 13 \mathrm{C}$ values, nitrogen isotope values $(\delta 15 \mathrm{~N})$ reveal information about the trophic position of an individual within a localised food resource. The advantage of the stable isotope method is the precise quantitative evaluation of the diet of humans and animals. It allows for the determination of the type of environment in which the subjects lived and their main food sources: plant, fish or terrestrial animal. It does not however allow us to distinguish different types of animal protein consumed by a subject, since meat and dairy products have the same isotopic value. Our research represents the first comprehensive study of the diet of the Yakut population which, to now, has been described through ethnographic studies only. The ancestors of the Yakuts (cow and horse breeders), populated the North East of Siberia, migrating from the South in the eleventh-thirteenth centuries AD (Okladnikov, 1955; Alexeev, 1996; Fedorova et al., 2013). People (Crubezy and Nikolaeva, 2017) and cattle (Librado et al., 2015) adapted to extreme climatic conditions with winter temperatures that could reach $-60^{\circ} \mathrm{C}$. When Russian expansion began in Yakutia in the 1620s, Yakuts settled in the lands between the Lena, Amga 
and Aldan rivers (a location currently referred to as "Central Yakutia"), as well as at the mouth of Viluy river in the west, and along Yana river in the North-East (Tokarev, 1940; Okladnikov, 1955; Gogolev, 1993). Their lifestyle was considerably transformed by Russian colonisation. After 1689, and the establishment of Yakut elites, inequalities increased (Crubezy and Nikolaeva, 2017). The number of bovines and horses owned by families determined their wealth. People without livestock were called "fishermen" suggesting that the poor had a diet based on fish. An important consumption of wild plants and larch bark has also been demonstrated in ethnographic studies (Lindenau, 1983; Middendorf, 1878; Shiman'skii, 1885; Seroshevskii, 1896). Agriculture, notably cereal crops, evolved from the 18th century. Following Christianisation, which spread from the 1750s and became dominant in the majority of the population by 1855 , led to the appearance of new dietary specificities. These were due to a notable increase in the prescription of religious fasts and other dietary restrictions throughout the year. Furthermore, ethnographic texts indicate that the Yakuts from Viluy had a more fish- based diet (Maak,1887; Ivanov, 2015). At the same time, burials reveal a number of animal bones and vessels with dairy products deposited as funerary meal (Crubezy and Alexeev, 2007, 2012). Geographically, the closest isotopic studies were conducted in the Baikal region on Neolithic (5800-3000 BC) and Early Bronze (3400-1700 BC) Age (Katzenberg and Weber, 1999; Katzenberg et al., 2009, 2012; Weber et al., 2011). It has been noticed that humans from Upper Lena exhibited the lowest $\delta 13 \mathrm{C}$ and $\delta 15 \mathrm{~N}$ values, indicating a diet based on local game and fish, when compared to the Baikal region and Angara valley where high values indicate mostly fish consumption (Katzenberg and Weber, 1999; Weber et al., 2011). In summary, these studies suggest that the diet of different archaeological cultures of Siberia was fluctuating through time and space due to their adaptation to the changing environment.

The main objective of this work is to better depict the diet of the Yakut population through by comparing an isotopic tool with ethnographic and archaeological studies. The study of ethnographic and historical texts enabled us to reveal several issues: (i) The relative importance of fish versus terrestrial resources in diet; (ii) The evolution of diet over time, especially under the Russian influence; (iii) The variation in diet depending on regions, and finally, (iv) The distinction in diet depending on economic status and sex. To test these hypotheses, we investigated the diet of ancient Yakuts using carbon $(\delta 13 \mathrm{C})$ and nitrogen $(\delta 15 \mathrm{~N})$ isotope analysis in 61 subjects. In order to examine possible chronological and spatial differences, samples were selected from four regions of Yakutia dating from the 15th to the 19th century AD. Social and economic distinctions were determined by means of archaeological evidence. 


\section{Materials and methods}

The French Archaeological Mission in Oriental Siberia (MAFSO) excavated more than 150 tombs dated from the 15 th to the 19th century that were well preserved by permafrost. For this study, we sampled the femur from 61 individuals (37 men, 20 women and 4 children). These originated from three large regions of cattle breeders, that are otherwise ecologically and economically very different. Central Yakutia $(n=36)$ is a large cattle breeding zone with numerous "alas" (thermokarstic lakes surrounded by pastures) (Crubezy and Alexeev, 2012). Viluy ( $\mathrm{n}=10$ ), is very humid and is known for its abundance of fish (Maak, 1887), and Verkhoyansk and Oymyakon $(\mathrm{n}=15)$ are regions of North Yakutia rich in wild game where hunting continues to provide a part of the diet of current populations (Figure 1).

Apart from geographic distribution and sex, we also divided the human remains into four major chronological eras (Crubezy and Alexeev 2007, 2012; Crubezy and Nikolaeva, 2017): before $1700 \operatorname{AD}(n=12)$ when the Russian influence was not yet evident in the tombs; from 1700 to $1750 \mathrm{AD}(\mathrm{n}=35)$ during the Yakut Golden Age which witnessed a lineage taking power in Yakutia (Crubezy and Nikolaeva, 2017); from 1750 to 1800 AD (n=9) after the collapse of the Golden Age notably following smallpox (Biagini et al., 2012) and tuberculosis epidemics (Dabernat et al., 2014); and after 1800 AD (n=5) with a growing Russian influence on the economy and lifestyle (Burnasheva, 2015). We also identified four socio-economic groups according to the presence and type of artefacts in the graves: graves containing no artefacts $(n=16)$, poor burials with one to five artefacts $(n=14)$, middle class graves with six to ten artefacts $(n=22)$, and a group of local elites with more than ten artefacts $(n=9)$ (Table 1). We also collected animal samples from burial grounds and completed this list with modern samples (mostly fish) (Table 2).

Pieces of 1-2 $\mathrm{cm}$ of human femur bone were cleaned and abraded to remove surface contaminants and then crushed into particles smaller than $1 \mathrm{~mm}$. Collagen was extracted according to Longin's protocol (Longin, 1971) with modifications by Brown (Brown et al., 1988). About $500 \mathrm{mg}$ samples were put in a solution of equal $5 \mathrm{ml}$ volumes of methanol and chloroform and ultrasonically cleaned for 15 min to eliminate lipids and humic contaminants. The samples were then rinsed with distilled water and demineralised with hydrochloric acid (5 $\mathrm{ml}$ of $1 \mathrm{M} \mathrm{HCl}$ ) for one hour in a rocking tube mixer. Once cleaned (i.e. the solution was not cloudy) the samples were put in hydrochloric acid at a low concentration $(10 \mathrm{ml}$ of $0.01 \mathrm{M} \mathrm{HCl})$ and solubilised in an oven at $90^{\circ} \mathrm{C}$ for 17 hours. The liquid was then filtered and frozen for more than 1 hour. The samples were finally freeze-dried for 48 hours. Five mg samples of the collagen extract were weighed in tin capsules which were combusted in a Flash EA 1112 
(Thermo Scientific) elemental analyser coupled in continuous flow to a Isoprime 100 (Elementar) isotope ratio mass spectrometer. Carbon and nitrogen isotope measurements were calibrated using in house standards of casein and aspartic acid, calibrated against international standards from the International Atomic Energy Agency, Vienna, Austria (IAEA-CH3, IAEACH6, IAEA-N1, IAEA-N2). The $\delta 13 \mathrm{C}$ and $\delta 15 \mathrm{~N}$ values were expressed relative to VPDB and AIR respectively, and are expressed in \%o of the deviation from the international standard using: $\delta \mathrm{X}=($ Rsample/ Rstandard -1$) \times 1000$, where $\mathrm{X}$ is $13 \mathrm{C}$ or $15 \mathrm{~N}$ and $\mathrm{R}$ is the isotope ratio of the sample or the standard (i.e. $13 \mathrm{C} / 12 \mathrm{C}$ or $15 \mathrm{~N} / 14 \mathrm{~N}$ ). Isotope analyses of "outliers" showing extremely low $\delta 15 \mathrm{~N}$ values have been repeated several times. The collagen extraction was carried out at the Ecole Nationale Supérieure (ENS), Lyon, Geology Laboratory and the carbon and nitrogen measurements were carried out at the "Isotope Ecology" platform of the Laboratoire d'Ecologie des Hydrosystèmes Naturels et Anthropisés (LEHNA) Laboratory, Lyon.

\section{Results}

\subsection{Faunal samples}

The $\delta 13 \mathrm{C}$ recorded in the collagen of domestic and wild terrestrial mammals showed that they all occupied the same ecosystem and did not consume marine plants or $\mathrm{C} 4$ photosynthesis terrestrial plants. The $\delta 13 \mathrm{C}$ value varied from -20.3 to $-22.7 \%$, with a mean value of $-21.6 \pm$ $0.8(1 \mathrm{SD}, \mathrm{n}=12)$. The highest isotopic values $(\delta 13 \mathrm{C}=-20.3 \%$ and $\delta 15 \mathrm{~N}=9.5 \%$ ) were observed in the dog which is the only omnivore (Figure 2).

The $\delta 15 \mathrm{~N}$ value of terrestrial herbivores ranged from $1.6 \%$ o to $8.0 \%$ with a mean value of 4.5 $\pm 1.7(1 \mathrm{SD}, \mathrm{n}=11)$. The horse $\delta 15 \mathrm{~N}$ values ranged from $3.5 \%$ o to $8.0 \%$ with a mean value of $4.9 \pm 1.4(1 \mathrm{SD}, \mathrm{n}=9)$. The samples of hare and bovine were lower, $3.4 \% 0$ and $1.6 \%$ respectively. The data on terrestrial animals are similar to previous studies on the region (Figure $3)$. The modern dog has similar values to the prehistoric dog from Upper Lena $(\delta 13 \mathrm{C}=-19.1 \%$; $\delta 15 \mathrm{~N}=9.7 \%$ ) (Weber, 2002); and exactly the same as a Neolithic wolf $(\delta 13 \mathrm{C}=-20.2 \% \circ ; \delta 15 \mathrm{~N}$ $=9.7 \%$ ) from the Baikal region (Losey et al., 2011) which indicates that its diet was based on terrestrial animals. Ordinarily, the dog is considered to feed on human leftovers. In this way its stable isotopes values can be used as indicator of a human diet from the same environment. Isotopic values for fish were very heterogeneous (Figure 2). Carbon isotopic values varied from -27.2 to $-24.3 \%$ with a mean value of $-25.9 \pm 1.3(1 \mathrm{SD}, \mathrm{n}=4)$ for river fish (dace, pike) to lake fish (carp) which ranged from -16.1 to $-11.5 \%$ o with a mean value of $-14.3 \pm 2.5(1 \mathrm{SD}, \mathrm{n}=3)$ except for the carp from the Nam region (Central Yakutia) with a $\delta 13 \mathrm{C}$ of $-29.8 \%$ and $\delta 15 \mathrm{~N}$ of $7.5 \%$ close to the value of pike from the same region $(\delta 13 \mathrm{C}=-25.6 \%$ o, $\delta 15 \mathrm{~N}=7.9 \%$ ). The 
$\delta 15 \mathrm{~N}$ of fish is higher than that of terrestrial herbivores (Katzenberg and Weber, 1999; O'Connell et al., 2003; Shishlina et al., 2009) and varies between 7.5 and 11.6\%o. Carp have $\delta 15 \mathrm{~N}$ values between 7.5 and $11.6 \%$ with a mean value of $9.6 \pm 1.7(1 \mathrm{SD}, \mathrm{n}=4)$. River fish have $\delta 15 \mathrm{~N}$ values between 7.9 and $9.1 \%$ with a mean value of $8.2 \pm 0.6(1 \mathrm{SD}, \mathrm{n}=4)$. The $\delta 15 \mathrm{~N}$ values of archaeological fish remains from Central Yakutia (site Jarama) is significantly higher $(11.6 \%$ o) than modern fish samples with an average $\delta 15 \mathrm{~N}$ value of $8.5 \pm 0.9(1 \mathrm{SD}, \mathrm{n}=7)$. Carbon stable isotopes values for carp are broadly in accordance with values of Baikal lake fish, and those of dace and pike match with Angara and Lena river fish values (Figure 3). In general, they show a wide range of $\delta 13 \mathrm{C}$ values which is explained by the fact that pelagic (open water) and benthic (deep water) fish have lower $\delta 13 \mathrm{C}$ values (about -24.6\%o) than species from littoral zones (-12.9\%o) (Katzenberg and Weber, 1999; Katzenberg et al., 2012). Finally, $\delta 15 \mathrm{~N}$ values of fish from Yakutia are lower than those presented in former studies. This can be explained by low primary productivity in Yakutia water systems (Weber, 2011).

\subsection{Human samples}

The $\delta 13 \mathrm{C}$ values for all human bones ranged between -22.0 to $-18.7 \%$ (Figure 2). The average was $-20.4 \% \circ \pm 0.6(1 \mathrm{SD}, \mathrm{n}=61)$ and is slightly higher than values of herbivores. It is equal to a one step change in trophic level, the average $\delta 13 \mathrm{C}$ value for herbivores being $-21.7 \% \circ \pm 0.7$ (1SD, $n=11)$. Occasional consumption of freshwater resources occurs. This is shown by the high $\delta 15 \mathrm{~N}$ values $(>9.5 \%$ ) of some individuals together with their low $\delta 13 \mathrm{C}$ values, indicative of consumption of freshwater fish. The lowest human $\delta 13 \mathrm{C}$ values are observed in three exceptional cases with extremely low $\delta 15 \mathrm{~N}$ values (Ordiogone 2: $\delta 13 \mathrm{C}=-21.1, \delta 15 \mathrm{~N}=5.3 \%$; At Daban 7: $\delta 13 \mathrm{C}=-21.9, \delta 15 \mathrm{~N}=4.4 \%$; Sytygane Sihe2: $\delta 13 \mathrm{C}=-22.0, \delta 15 \mathrm{~N}=4.9 \%$ ) . Their low $\delta 15 \mathrm{~N}$ value is similar to those found for the herbivore specimens analysed and attests to the importance of plants in their diet to the detriment of animal proteins. Nevertheless, we do not completely exclude the possibility of wrong identification of faunal samples as human. One old man from the Viluy region (Tungus Keul 5: $\delta 13 \mathrm{C}=-21.3 \%$; $\delta 15 \mathrm{~N}=11.6 \%$ ) also has one of the lowest $\delta 13 \mathrm{C}$ values but, considering its high $\delta 15 \mathrm{~N}$ value, this suggests a mainly fishbased diet in this case. The $\delta 15 \mathrm{~N}$ values for all human bones ranged between $4.4 \%$ o to $12.9 \%$ o (Figure 2). The $\delta 15 \mathrm{~N}$ value of individuals consuming mainly the meat and dairy products of terrestrial animals is estimated to be in the range of 7.5 to $9.5 \%$ o $(n=4)$, while values higher than $11.2 \%$ o can indicate a diet rich in fish $(n=23)$. We presume that $\delta 15 \mathrm{~N}$ values between 9.5 and $11.2 \%$ indicate a mixed diet in which fish and meat have the same importance $(\mathrm{n}=31)$. Three samples noted above with significantly low $\delta 15 \mathrm{~N}$ values: $4.4 \%$, $4.9 \%$, and $5.3 \%$, two 
from Central Yakutia and one from Viluy, respectively (all masculine) dating from the 18th century are considered as outliers and we did not include them in comparison studies presented below.

\subsection{Dietary differences between phases and regions}

The variability of $\delta 13 \mathrm{C}$ values is higher in Central Yakutia with a range of $2.9 \%$ and Viluy (where the range is $2.6 \%$ ) than in North (where the range is $1 \%$ ). This suggests that varying proportions of plant and animal food may exist in the diet typical of Central Yakutia and the Viluy river, while a more uniform diet may have been practiced in the Northern regions. The variability of $\delta 13 \mathrm{C}$ values is also higher before $1700 \mathrm{AD}(\delta 13 \mathrm{C}=-20.1 \% \circ \pm 0.74,1 \mathrm{SD}, \mathrm{n}=12)$ than during $1700-1750 \mathrm{AD}(\delta 13 \mathrm{C}=-20.5 \%$ $\pm 0.50,1 \mathrm{SD}, \mathrm{n}=28)$, during $1750-1800 \mathrm{AD}(\delta 13 \mathrm{C}$ $=-20.4 \% \circ \pm 0.56,1 \mathrm{SD}, \mathrm{n}=16)$, and after $1800 \mathrm{AD}(\delta 13 \mathrm{C}=-20.6 \% \circ \pm 0.25,1 \mathrm{SD}, \mathrm{n}=5)$. Values of $\delta 15 \mathrm{~N}$ are the highest in the Viluy region with a mean $\delta 15 \mathrm{~N}$ value of $11.7 \% \circ \pm 0.9(1 \mathrm{SD}, \mathrm{n}=$ 9). Samples from Central Yakutia show the largest range of $\delta 15 \mathrm{~N}$ values which vary from 9.5 to $11.9 \%$ o $(\delta 15 \mathrm{~N}=11.0 \% \circ \pm 0.7,1 \mathrm{SD}, \mathrm{n}=34)$. These values indicate an important role of fish in the diet of individuals from these two regions. Lower $\delta 15 \mathrm{~N}$ values are found in the North (Indiguirka and Verkhoyansk) with a mean $\delta 15 \mathrm{~N}$ value of $10.0 \% \circ \pm 0.5(1 \mathrm{SD}, \mathrm{n}=15)$, which indicates a diet based on meat and dairy products of terrestrial herbivores in addition to plants (Figure 2).

The comparison of the $\mathrm{C}$ and $\mathrm{N}$ stable isotope evidence for ancient Yakut with Neolithic and Early Bronze Age humans of the Cis-Baikal area shows both regional and temporal variations in diet and subsistence (Figure 3). The Yakut horse-breeder $\delta 13 \mathrm{C}$ and $\delta 15 \mathrm{~N}$ values $(\delta 13 \mathrm{C}=-$ $20.4 \pm 0.5, \delta 15 \mathrm{~N}=10.8 \pm 0.9(1 \mathrm{SD}, \mathrm{n}=58)$ indicate a meat and fish-based diet due to the light isotopic values of fish in this geographical area. They appear lighter compared to foragers of the Baikal region. The difference is significant when it comes to the Little Sea $(\delta 13 \mathrm{C}=-$ $18.2 \pm 3.8, \quad \delta 15 \mathrm{~N}=14.0 \pm 1.6 \quad(1 \mathrm{SD}, \mathrm{n}=101)$, South-western Baikal $(\delta 13 \mathrm{C}=-16.3 \pm 0.7$, $\delta 15 \mathrm{~N}=14.6 \pm 1.0(1 \mathrm{SD}, \mathrm{n}=62)$ or Angara valley $(\delta 13 \mathrm{C}=-16.7 \pm 1.4, \delta 15 \mathrm{~N}=13.2 \pm 1.4(1 \mathrm{SD}$, $\mathrm{n}=119$ ) where fish and sometimes seal meat from the Baikal seem important in the diet of hunters-gatherers. In the meantime, these values are close to the foragers of Upper Lena $(\delta 13 \mathrm{C}=$ $-19.8 \pm 0.5, \delta 15 \mathrm{~N}=11.0 \pm 1.1(1 \mathrm{SD}, \mathrm{n}=28)$ characterised by consumption of local fish and meat.

\subsection{Dietary differences between male and female and between socio-economic groups}

When comparing the diet of males and females, we did not distinguish individuals by regions and periods but included all samples from 1700 to post 1800 where both women $(n=21)$ and 
men $(n=25)$ were represented. The average of both $\delta 15 \mathrm{~N}$ and $\delta 13 \mathrm{C}$ values were found to be exactly the same for male $(\delta 13 \mathrm{C}=-20.4 \% \circ \pm 0.4$ and $\delta 15 \mathrm{~N}=10.8 \% \circ \pm 0.8,1 \mathrm{SD}, \mathrm{n}=25)$ and female $(\delta 13 \mathrm{C}=-20.4 \% \circ \pm 0.3$ and $\delta 15 \mathrm{~N}=10.8 \% \circ \pm 0.8,1 \mathrm{SD}, \mathrm{n}=21)$ samples, highlighting similar dietary habits among genders. Pairwise comparisons of socio-economic groups do not show isotopic variations depending on social status. However, the variability of both $\delta 15 \mathrm{~N}$ and $\delta 13 \mathrm{C}$ values of local elite group's individuals is lower than for other social groups ("elites": $\delta 13 \mathrm{C}=-20.4 \% \circ \pm 0.1$ and $\delta 15 \mathrm{~N}=11.2 \% \circ \pm 0.5,1 \mathrm{SD}, \mathrm{n}=9$, "middle group": $\delta 13 \mathrm{C}=-20.5 \% \circ \pm$ 0.3 and $\delta 15 \mathrm{~N}=10.5 \% \circ \pm 0.8,1 \mathrm{SD}, \mathrm{n}=20$; "poor": $\delta 13 \mathrm{C}=-20.1 \% \circ \pm 0.5$ and $\delta 15 \mathrm{~N}=11.3 \% \circ \pm$ $1.1,1 \mathrm{SD}, \mathrm{n}=13$, and tombs without material: $\delta 13 \mathrm{C}=-20.4 \% \circ \pm 0.6$ and $\delta 15 \mathrm{~N}=10.7 \% \circ \pm 0.7$, $1 \mathrm{SD}, \mathrm{n}=16$ ). This suggests that they had a more stable diet than other social groups.

\section{Discussion}

The differences between species of herbivore animals depend on variations in the isotopic composition of the plants consumed, digestive processes and ecological factors. Generally, the isotopic data of herbivores are higher in arid than in humid zones (Ambrose, 1991; Bocherens, 1999). This is the case in Yakutia. The high $\delta 15 \mathrm{~N}$ values in horse samples are characteristic for young animals and can be explained by the fact that they are suckled until being slaughtered (Bocherens, 1999). Yakuts are unique horse breeders who commonly slaughter young animals at the age of eight or nine months for climatic and economic reasons, (born in March, foals grow up and gain weight until November, a month with sufficiently stable cold temperatures to keep meat outside). The difference in isotopic values between the herbivores and the dog $(\delta 15 \mathrm{~N}=5.0 \%$ and $\delta 13 \mathrm{C}=1.4 \% \circ)$ shows an enrichment in animal protein content with one trophic level leading the dog values to be comparable to human values, suggesting a diet based mostly on terrestrial animals. Regarding aquatic resources, we propose that the important variability of $\delta 13 \mathrm{C}$ and $\delta 15 \mathrm{~N}$ values of fish samples is due to differences in trophic sources and vegetation in lakes and rivers in Yakutia. However, the $\mathrm{C}$ and $\mathrm{N}$ isotopic signatures of fish analysed in the present study show good similarities with those of the Baikal Lake and adjacent regions (Figure $3)$.

The distribution of $\delta 13 \mathrm{C}$ and $\delta 15 \mathrm{~N}$ values illustrates the variety of dietary behaviours of Yakuts. We observed the existence of different trophic/dietary zones: that of consumers of terrestrial herbivores in the North, a group in Viluy with a diet rich in fish; and a group with a diverse diet in Central Yakutia. These results are in accordance with ethnological literature (Maak, 1887; Hudiakov, 1969) that shows a more varied diet in Central Yakutia than in the two other regions. We did not identify a clear difference between men and women, however a difference between social groups is evident with a regular consumption of meat and milk for subjects associated 
with rich tombs compared to those associated with modest tombs. This also confirms ethnological data (Seroshevskii, 1896; Maak, 1887). High $\delta 15 \mathrm{~N}$ values in the earlier phase can be due to a significant consumption of fish and herbivore protein, mainly, foal meat, before the 17 th century, which slowly decreased during the 18 th century.

Archaeological data attests to horse breeding and consumption, and to a lesser extent, cattle breeding and hunting, while there is occasional evidence for fishing and fish consumption. Among 61 analysed tombs, 16 did not have any archaeological artefacts, while 45 included some indications of diet such as vessels and/or meat and dairy products (Figure 4). The tombs did not contain any fish remains, probably for the reason that fish was not considered to be honorific as being a part funeral meal. The crucian carp bones investigated for this work come from the Jarama site where a few fish bones were discovered outside of the coffins of three child tombs. Funeral meals in analysed human tombs consists mostly of meat remains (38/45), and sometimes were associated with dairy products (12 cases). Milk product is rarely deposited by itself (3/45), nevertheless numerous vessels present in almost all tombs with artefacts (43/45) could initially have contained milk. Comparing our results tomb by tomb with archaeological data, we noted certain points: the Taralay subject, prior to $1700 \mathrm{AD}$, has one the highest $\delta 15 \mathrm{~N}$ value $(12.7 \%$ o $)$ which indicates a fish-based diet. This was the only tomb in which we found a fishing tool among funerary artefacts (a larch pick-axe used to break the ice for fishing during winter) (Figure 5).

Three subjects had an extremely low $\delta 15 \mathrm{~N}$ value, comparable to that of terrestrial herbivores. This defines that, at least during the last 8 years of their life (a timespan considered to affect the isotopic value), they had a dominantly vegetarian diet. In the tombs of these three subjects, however, the remains of funerary meals contained dairy and horse meat. Among these three subjects, two older men had lost almost all their teeth before death, which might indicate a soft vegetarian diet rather than a meat-based diet. Physiological effects such as starvation, and inversely overconsumption may also influence $\delta 15 \mathrm{~N}$ values (Hedges and Reynard, 2007; Balter et al., 2006). Multiple ethnographical and historical sources attest to the importance of plants and larch bark's flour in the diet of the Yakuts, in particular for poor people. There may have been a possibility of mis-identification of samples. New sampling of the specified burials will therefore have to be conducted.

\section{Conclusions}

The diet of Yakut population from 15th to 19th centuries appears relatively homogeneous according to ethnographic data. However, $\delta 13 \mathrm{C}$ and $\delta 15 \mathrm{~N}$ values demonstrate a clear distinction between different geographical areas of Yakutia. We also documented variations in 
dietary habits related to social status. Men and women had the same type of diet. These results are correlated with ethnographical and historical evidences. We noticed considerable variation in $\delta 15 \mathrm{~N}$ values for terrestrial animals while $\delta 13 \mathrm{C}$ turned out to be a less significant variable. We found that the $\mathrm{N}$ isotope composition of suckling horses was notably elevated. We also confirmed the existence of wide variation in $\delta 13 \mathrm{C}$ and $\delta 15 \mathrm{~N}$ among fish from rivers and lakes. This indicates that the high $\delta 15 \mathrm{~N}$ values measured in humans could be explained not solely by an intake of freshwater fish, but also by the consumption of young animals, especially foals. In this context, it would be interesting to analyse the isotopes of sulphur and strontium/calcium and barium/calcium ratios (Balter et al., 2001; Balter and Simon, 2006) to distinguish the consumption of freshwater fish and terrestrial animals (Privat et al., 2007).

\section{Captions for figures and tables}

Figure 1. Localisation of the studied areas

Figure 2. Carbon and nitrogen isotopic results of the study. The close-up is given for humans.

Figure 3. Carbon and nitrogen isotopic results of the present study in the context of available isotopic data of the Baikal Lake and adjacent areas. Data are from Katzenberg and Weber, 1999; Katzenberg et al., 2009; Katzenberg et al., 2012; Weber et al., 2011.

Figure 4 . The ribs of the horse and the ritual cup tchoron with the dairy product in the tomb Kerdugen, 1700-1750 AD

Figure 5. Fishing tool in the tomb Taralay, Central Yakutia, before 1700

Table 1. Carbon and nitrogen isotopic results for human samples. Isotope values are expressed in per mil. The social status is determined by number of artefacts: $\bigcirc-$ no material $\bullet-$ poor $(1$ to 5 artefacts). $\bullet \bullet-$ middle (6 to 10 artefacts). $\bullet \bullet \bullet-$ rich (more than 10 artefacts).

Table 2. Carbon and nitrogen isotopic results for animal samples. Isotope values are expressed in per mil

\section{Acknowledgments}

This research is supported by the French Archaeological Mission in Oriental Siberia (Ministry of Foreign and European Affairs, France), French Embassy in Russia, North-Eastern Federal University (Yakutsk, Sakha Republic), and the Human Adaptation program of the French Polar Institute Paul Émile Victor. We thank the anonymous reviewers for their insightful comments and suggestions. Special thanks to Dr. Richard Fosse for his careful reading of our manuscript.

\section{Bibliography}


1. Alexeev, A., 1996. Drevniaia Iakutiia: zheleznyi vek i epokha Srednevekov'ia (Ancient Yakutia: The Iron Age and the Medieval Epoch), Novosibirsk, Izdatel'stvo Instituta Arkheologii i Etnografii SO RAN. [In Russian].

2. Ambrose, S., 1991. Effects of diet, climate and physiology on nitrogen isotope abundances in terrestrial foodwebs. J. Archaeol. Sci. 18 (3), 293-317. https://doi.org/10.1016/0305-4403(91)90067-Y.

3. Balter, V., Person, A., Labourdette, N., Drucker, D., Renard, M., Vandermeersch, B., 2001. Were Neandertalians essentially carnivores? Sr and Ba preliminary results of the mammalian palaeobiocoenosis of Saint-Césaire. CR AC S IIA. 332(1), 59-65.

4. Balter, V., Simon, L., Fouillet, H., Lécuyer, C., 2006. Box-modeling of ${ }^{15} \mathrm{~N} /{ }^{14} \mathrm{~N}$ in mammals. Oecologia. 147, 212-222. https://doi.org/10.1007/s00442-005-0263-5.

5. Balter, V., Simon, L., 2006. Diet and behavior of the Saint-Césaire Neanderthal inferred from biogeochemical data inversion. J. Hum. Evol. 51, 329-338. https://doi.org/10.1016/j.jhevol.2006.04.008.

6. Biagini, P ., Thèves, C., Balaresque, P., Géraut, A., Cannet, C., Keyser, C., Nikolaeva, D., Gérard, P., Duchesne, S., Orlando, L., Willerslev, E., Alekseev, A.N., de Micco, P., Ludes, B., Crubézy, E., 2012. Variola Virus in a 300-Year-Old Siberian Mummy. New Engl. J. Med. 376(21), 2057-59. https://doi.org/10.1056/NEJMc1208124.

7. Bocherens, H., 1999. Isotopes stables et reconstitution du régime alimentaire des hominidés fossiles: une revue. In: Bulletins et Mémoires de la Société d'anthropologie de Paris, Nouvelle Série 11 (3-4), 261-287.

8. Bocherens, H., Drucker D., 2003. Trophic level isotopic enrichment of carbon and nitrogen in bone collagen: case studies from recent and ancient terrestrial ecosystems. Int. J. of Osteoarchaeol. 13(1-2), 46-53. https://doi.org/10.1002/oa.662.

9. Brown, T.A., Nelson, D.E., Vogel, J.S., Southon, J.R., 1988. Improved collagen extraction by modified Longin method. Radiocarbon. 30(2), 171-177

10. Burnasheva, N.I., 2005. Ekonomika Iakutii v XIX veke: pervye shagi k rynochnym otnosheniiam (The economy of Yakutia in the 19th century: the first steps to market relations). Cevero-Vostochnyi gumanitarnyi vestnik. 2(11), 15-19. [In Russian].

11. Crubézy, E., Alexeev, A., 2007. Chamane, kyys jeune fille des glaces. Errance, Paris.

12. Crubézy, E. Alexeev, A., 2012. Mir drevnikh Iakutov: opyt mezhdisciplinarnykh issledovanii (The world of the ancient Yakuts : a transdisciplinary approach from the French/Yakut expedition). Yakutsk. [In Russian].

13. Crubézy, E., Nikolaeva, D., 2017. Vainqueurs Ou Vaincus ? Odile Jacob, Paris. 
14. Dabernat, H., Thèves, C., Bouakaze, C., Nikolaeva, D., Keyser, C., Mokrousov, I., Géraut, A., Duchesne, S., Gérard, P., Alexeev, A.N., Crubézy, E., Ludes, B., 2014. Tuberculosis Epidemiology and Selection in an Autochthonous Siberian Population from the 16th-19th Century. Plos One. 9(2). https://doi.org/10.1371/journal.pone.0089877.

15. Fedorova, S.A., Reidla, M., Metspalu, E., Metspalu, M., Rootsi, S., Tambets, K., Trofimova, N., Zhadanov, S.I., Hooshiar Kashani, B., Olivieri, A., Voevoda, M.I., Osipova, L.P., Platonov, F.A., Tomsky, M.I., Khusnutdinova, E.K., Torroni, A., Villems, R., 2013. Autosomal and uniparental portraits of the native populations of Sakha (Yakutia): implications for the peopling of Northeast Eurasia. BMC Evol. Biol. 13:127. https://doi.org/10.1186/1471-2148-13-127.

16. Gogolev, A., 1993. Iakuty (problemy etnogeneza i formirovaniia kul'tury) (Yakuts (problems of ethnogenesis and culture formation)). Yagu, Yakutsk. [In Russian].

17. Hedges, R.E.M., Reynard, L., 2007. Nitrogen isotopes and the trophic level of humans in archaeology. J. Archaeol. Sci. 34 (8), 1240-1251. https://doi.org/10.1016/j.jas.2006.10.015.

18. Hudiakov, I. A. 1969. Kratkoe opisanie Verhoianskogo okruga (Brief description of the district of Verkhoyansk). Leningrad. [In Russian].

19. Katzenberg, A.M., Weber, A.W., 1999. Stable isotope ecology and paleodiet in the Lake Baikal region of Siberia. J. Archaeol. Sci. 26(6), 651-659.

20. Katzenberg, M.A., Goriunova, O.I., Weber, A.W., 2009. Paleodiet reconstruction of Bronze Age Siberians from the mortuary site of Khuzhir-Nuge XIV, Lake Baikal. J. Archaeol. Sci. 36 (2), 663-674. https://doi.org/10.1016/j.jas.2008.10.012.

21. Katzenberg, M.A., McKenzie, H.G., Losey, R.J., Goriunova, O.I., Weber, A.W., 2012. Prehistoric dietary adaptations among hunter-fisher-gatherers from the Little Sea of Lake Baikal, Siberia, Russian Federation. J. Archaeol. Sci. 39(8), 2612-2626. https://doi.org/10.1016/j.jas.2011.08.010.

22. Katzenberg, M.A., Waters-Rist, A.L., 2018. Stable isotope analysis: a tool for studying past diet, demography and life history, In: Katzenberg, M.A., Grauer, A.L. (Eds.), Biological anthropology of the human skeleton, third ed. Wiley-Blackwell, pp. 469-504.

23. Librado, P. Der Sarkissian, C., Ermini, L., Schubert, M., Jónsson, H., Albrechtsen, A., Fumagalli, M., Yang, M.A., Gamba, C., Seguin-Orlando A., Mortensen, C.D, Petersen, B, Hoover, C.A., Lorente-Galdos, B., Nedoluzhko, A., Boulygina, E., Tsygankova, S., Neuditschko, M., Jagannathan, V., Thèves, C., Alfarhan, A.H., Alquraishi, S.A., Al- 
Rasheid, K.A., Sicheritz-Ponten, T., Popov, R., Grigoriev, S., Alekseev. A.N., Rubin, E.M., McCue, M., Rieder, S., Leeb, T., Tikhonov, A., Crubézy, E., Slatkin, M., Marques-Bonet, T, Nielsen, R., Willerslev, E; Kantanen, J ., Prokhortchouk, E., Orlando, L., 2015. Tracking the Origins of Yakutian Horses and the Genetic Basis for Their Fast Adaptation to Subarctic Environments. Proc. Natl. Acad. Sci. U. S. A. 112(50), E6889-97. https://doi.org/doi: 10.1073/pnas.1513696112.

24. Lindenau, J., 1983. Opisanie narodov Sibiri (pervaia polovina 18 veka) (Description of the peoples of Siberia (first half of the 18th century)). Magadan Book Publishing, Magadan [In Russian].

25. Longin, R., 1971. New method of collagen extraction for radiocarbon dating. Nature. 230, 241-242.

26. Losey, R.J., Bazaliiskii, V.I., Garvie-Lok, S., Germonpré, M., Leonard, J.A., Allen, A.L., Katzenberg, M.A., Sablin, M.V., 2011. Canids as persons: Early Neolithic dog and wolf burials, Cis-Baikal, Siberia. J. Anthropol. Archaeol. 30/2, 174-189. https://doi.org/10.1016/j.jaa.2011.01.001.

27. Maak, R., 1887. Viliuiskii okrug Iakutskoj volosti (Vilyuisk district of the Yakut). P.3, Tipografiia i khromolitografiia A. Transhelia, SPb. [In Russian].

28. Marchenko, Z. V., Orlova, L.A., Panov, V.S., Zubova, A.V., Molodin, V.I., Pozdnyakova, O.A., Grishin, A.E., Uslamin, E.A., 2015. Paleodiet, radiocarbon chronology, and the possibility of fresh-water reservoir effect for Preobrazhenka 6 burial ground, Western Siberia: preliminary results. Radiocarbon. 57(4), 595-610. https://doi.org/10.2458/azu_rc.57.18435.

29. Middendorf, A. 1878. Puteshestvie na sever i vostok Sibiri: Sever i vostok Sibiri v estestvenno-istoricheskom otnoshenii. Korennye zhiteli Sibiri (Journey to the north and east of Siberia: North and east of Siberia in a natural-historical sense. Indigenous people of Siberia). Typography of the Imperial Academy of Sciences, Spb. [In Russian].

30. Molodin, V.I., Durakov, I.A., Kobeleva, L.S., Koneva, L.A., 2015. Fish in the burial rite of Andronovo (Fedorovka) people, based on Tartas-1 cemetery. Archaeol. Ethnol. \& Anthropol. of Eurasia. 43/3, 77-90. https://doi.org/10.1016/j.aeae.2015.11.008.

31. Murphy, E.M., Schulting, R., Beer, N., Chistov, Y., Kasparov, A., Pshenitsyna, M., 2013. Iron Age pastoral nomadism and agriculture in the Eastern Eurasian steppe: implications from dental palaeopathology and stable carbon and nitrogen isotopes. J. Archaeol. Sci. 40, 2547-2560. https://doi.org/10.1016/j.jas.2012.09.038.

32. O'Connell, T.C., Levine, M.A., Hedges, R.E.M., 2003. The importance of fish in the 
diet of central Eurasian peoples from the Mesolithic to the Early Iron Age. In Prehistoric Steppe Adaptation and the Horse. Cambridge Univ. Press., Cambridge, pp. 253-268.

33. O’Connell, T.C., Kneale, C.J., Tasevska, N., Kuhnle, G.G.C., 2012. The diet-body offset in human nitrogen isotopic values: a controlled dietary study. Am. J. Phys. Anthropol. 149, 426-434. https://doi.org/10.1002/ajpa.22140.

34. Okladnikov, A., 1955. Istoriia Yakutskoi ASSR: Yakutiia do prisoedineniia k russkomu gosudarstvu. Izdatel'stvo Akademii nauk SSSR (History of the Yakut A.S.S.R.: Yakutia before joining the Russian state). Publishing House of the Academy of Sciences of the USSR. [In Russian].

35. Privat, K.L., Schneeweiss, J., Benecke, N., Vasiliev, S.K., O’Connell, T.C., Hedges, R.E.M., Craig, O., 2005. Economy and diet at the Late Bronze Age/Iron Age site of Chicha: artefactual, archaeozoological and biochemical analyses. Eurasia Antiqua. 11: 419-448.

36. Privat, K.L., O'Connell, T.C., Hedges, R.E.M., 2007. The distinction between freshwater- and terrestrial-based diets: methodological concerns and archaeological applications of sulphur stable isotope analysis. J. Archaeol. Sci. 34, 1197-1204. https://doi.org/10.1016/j.jas.2006.10.008.

37. Schoeninger, M.J., De Niro, M.J., 1984. Nitrogen and carbon isotopic composition of bone collagen from marine and terrestrial animals. Geochimica et Cosmochimica Acta. 48 (4), 625-639.

38. Seroshevskii, V.L., 1896. Iakuty (The Yakuts). V.1. Spb. [In Russian].

39. Shishlina, N.I., Zazovskaya, E.P., Plicht, J. van der, Hedges, R. E. M., Sevastyanov, V.S., Chchagova, O.A., 2009. Paleoecology, subsistence, and 14C. chronology of the Eurasian Caspian steppe Bronze Age. 51/2, 481-49.

40. Svyatko, S.V., Schulting, R.J., Mallory, J., Murphy, E.M., Reimer, P.J., Khartanovich, V.I., Chistov, Y.K., Sablin, M.V., 2013. Stable isotope dietary analysis of prehistoric populations from the Minusinsk Basin, Southern Siberia, Russia: a new chronological framework for the introduction of millet to the Eastern Eurasian steppe. J. of Archaeol. S. 40, 3936-3945. https://doi.org/10.1016/j.jas.2013.05.005.

41. Svyatko, S. V., 2014. Dental palaeopathological analysis of the eneolithic-early iron age populations from the minusinsk basin, southern siberia: palaeodietary implications. Archaeol. Ethnol. \& Anthropol. of Eurasia 42/2: 143-156. https://doi.org/10.1016/j.aeae.2015.01.014. 
42. Shimanskii, A. I., 1885. Pishcha iakutov. (Yakuts food). VSO IRGO. Printing house N. N. Sinitsina, Irkutsk, 16, 310-319. [In Russian].

43. Tokarev, S., 1940. Ocherk istorii yakutskogo naroda (Essay on the history of the Yakut people). Moscow. [In Russian].

44. Weber, A.W., White, D., Bazaliiskii, V.I., Goriunova, O.I., Savel'ev, N.A., Katzenberg, M.A., 2011. Hunter-gatherer foraging ranges, migrations, and travel in the middle Holocene Baikal region of Siberia: Insights from carbon and nitrogen stable isotope $\begin{array}{llll}\text { signatures. } & \text { J. Anthropol. }\end{array}$ https://doi.org/10.1016/j.jaa.2011.06.006.

This research did not receive any specific grant from funding agencies in the public, commercial, or not-for-profit sectors. Declarations of interest: none. 

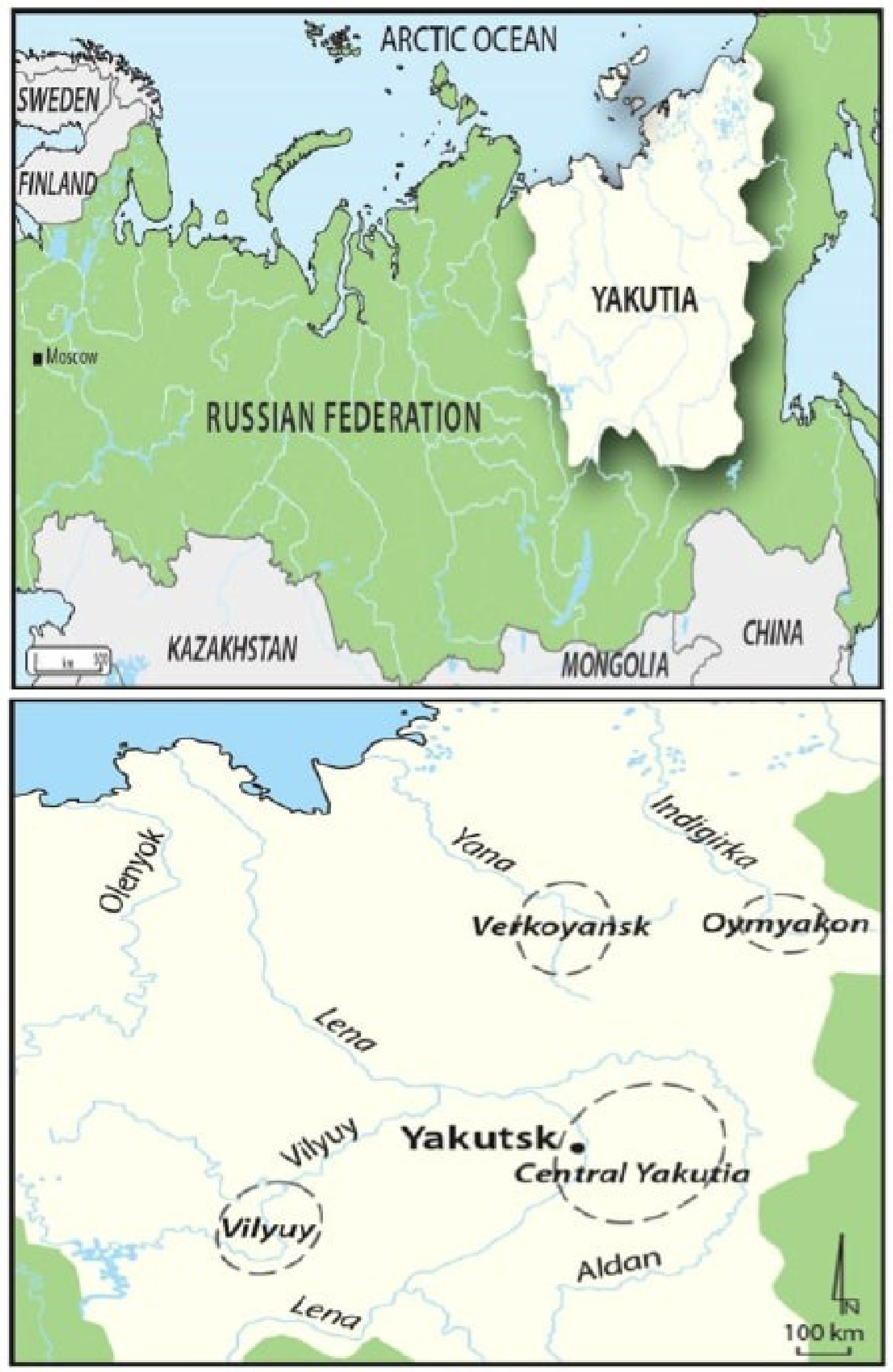


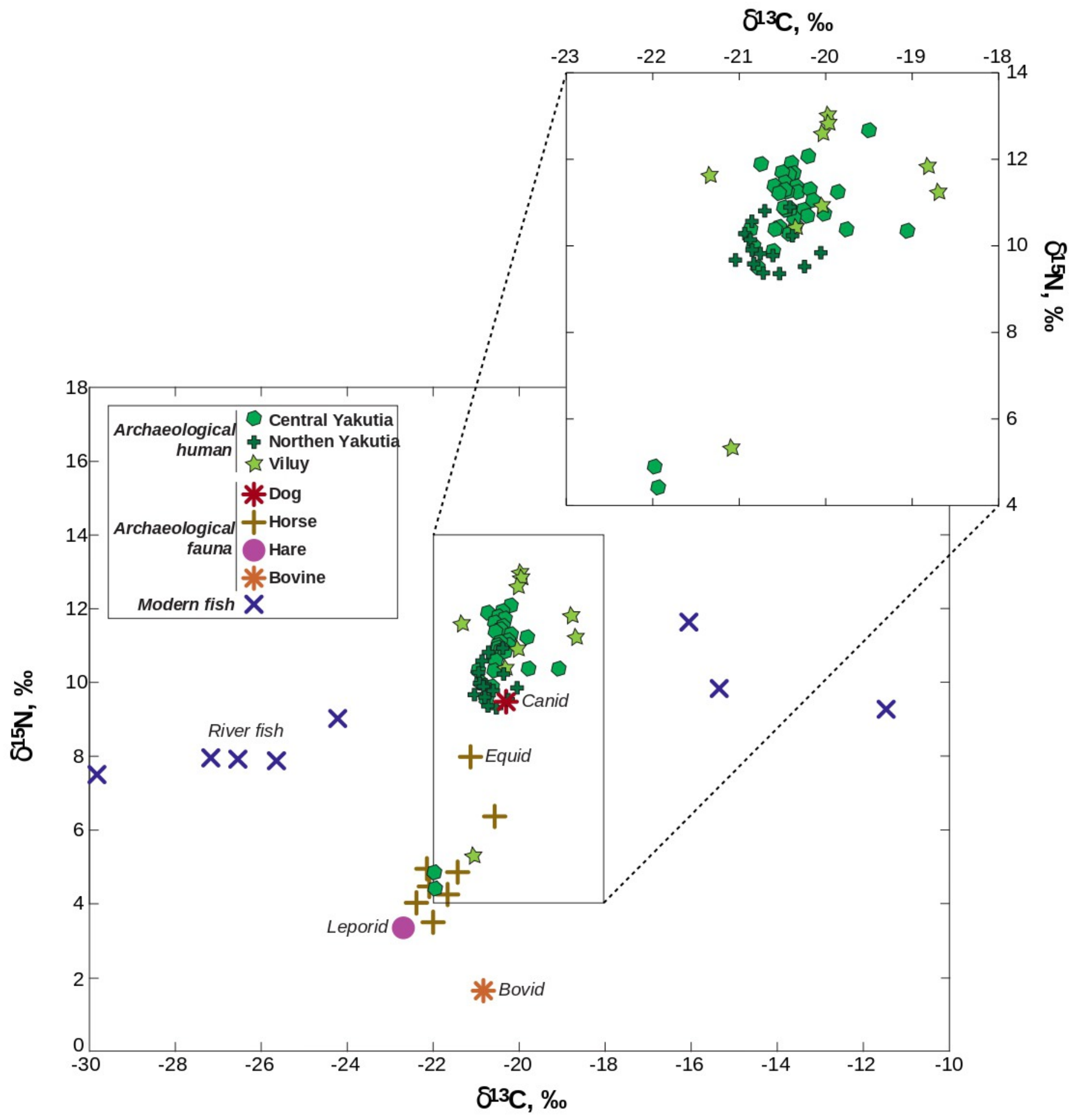




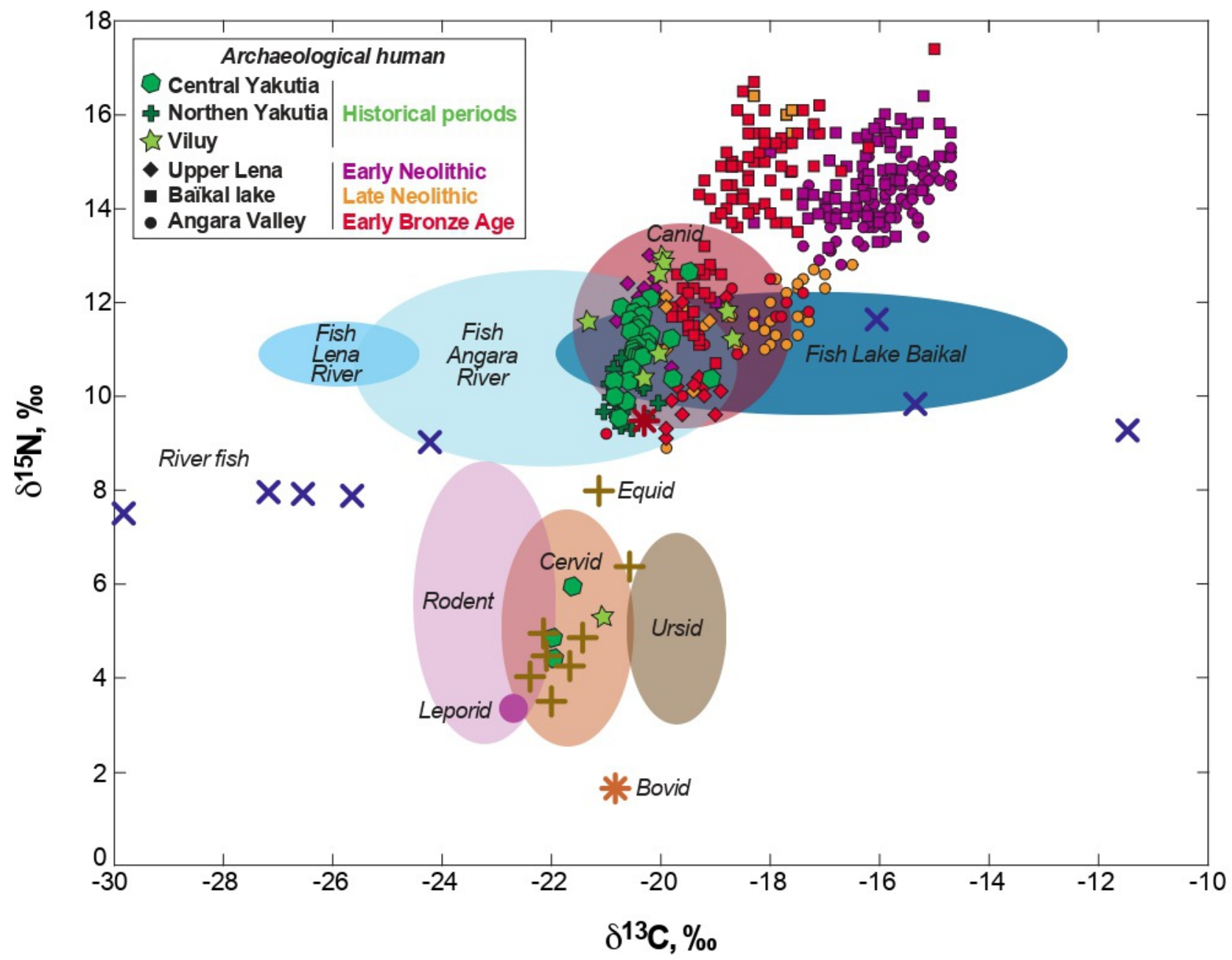




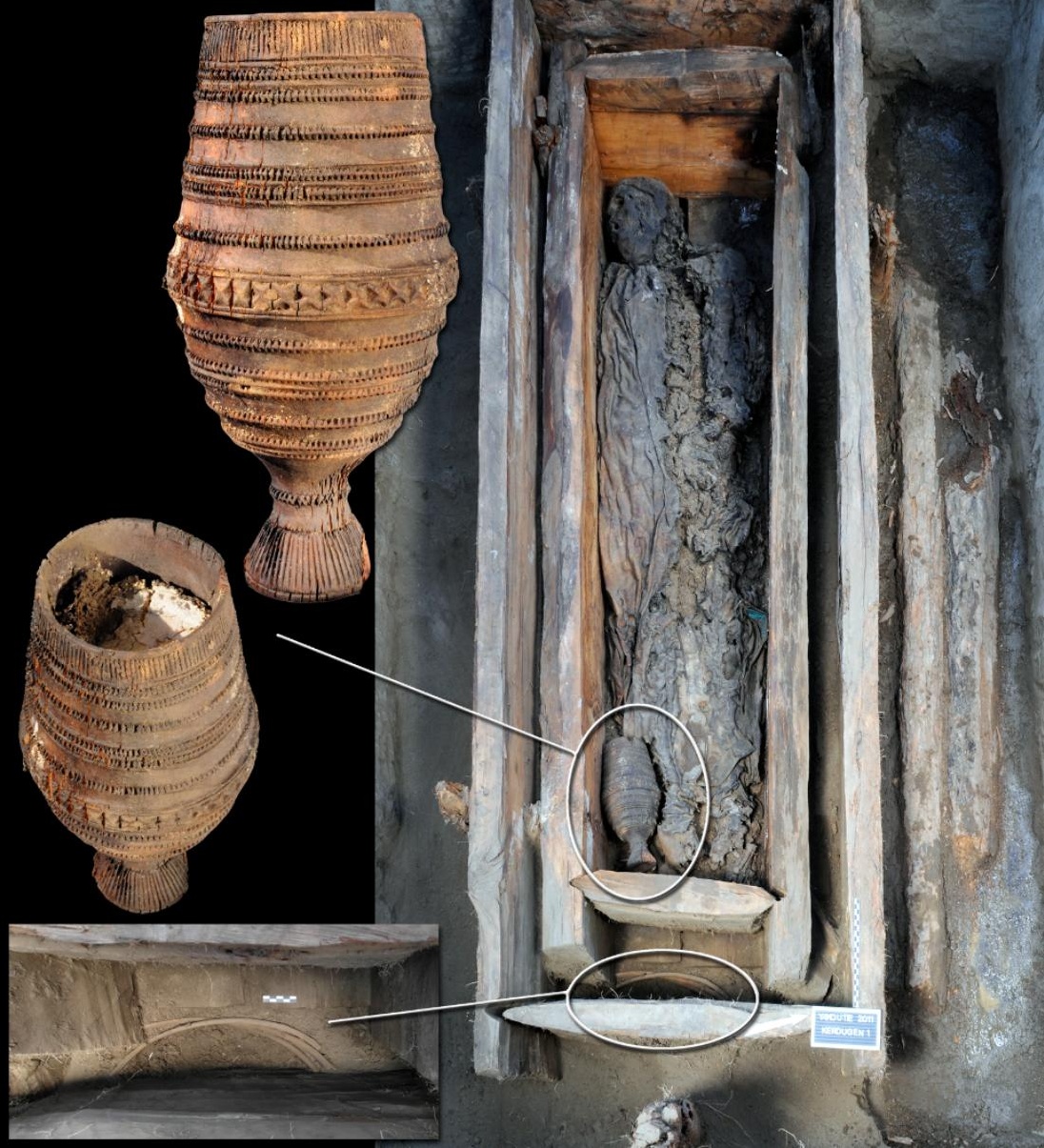




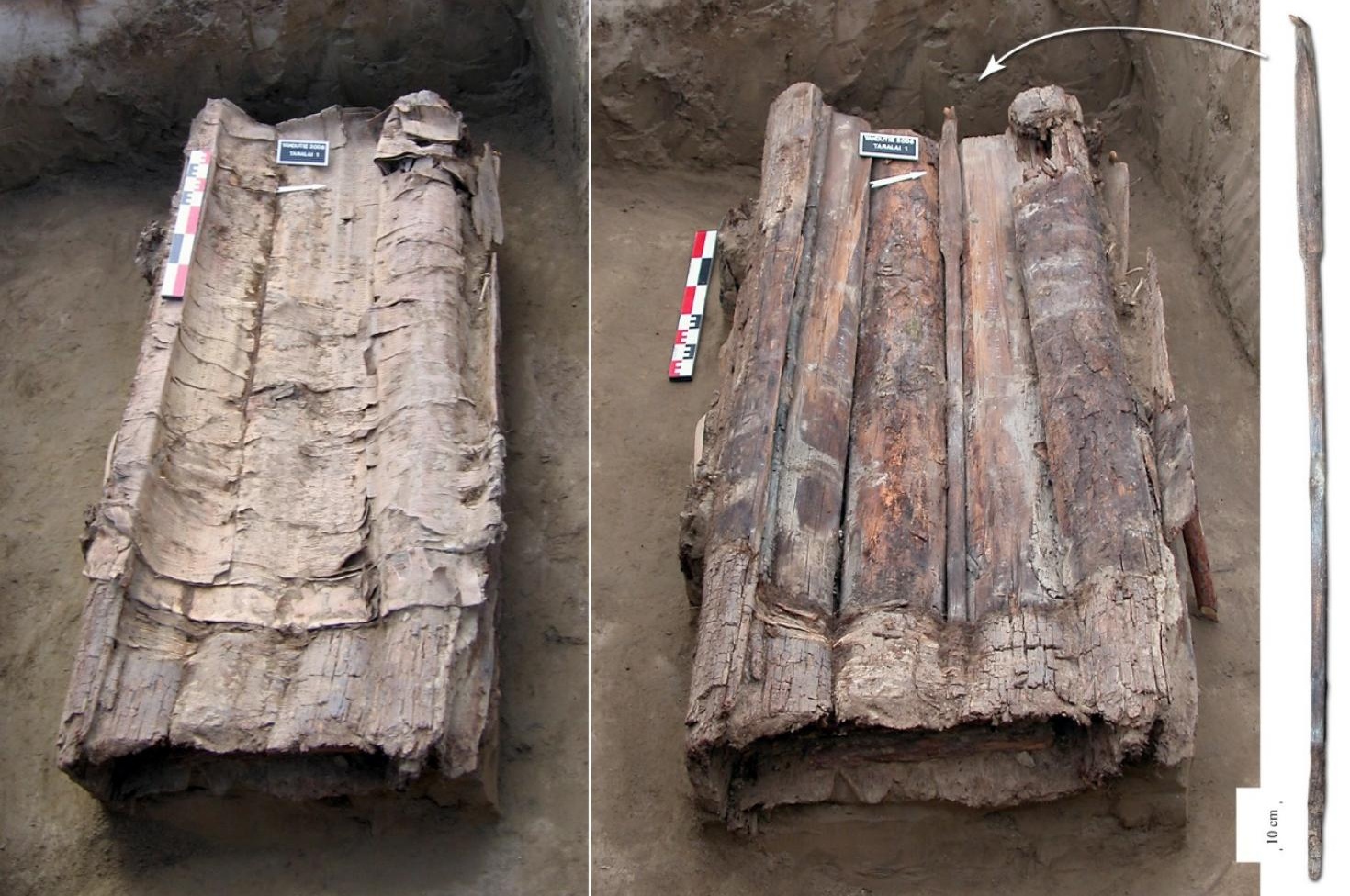




\begin{tabular}{|c|c|c|c|c|c|c|c|}
\hline Species & Site & Region & $\delta^{13} \mathrm{C}$ & $\delta^{15} N$ & $\begin{array}{c}\text { Elemental } \\
\text { composition } \\
\% \mathrm{C}\end{array}$ & $\begin{array}{c}\text { Elemental } \\
\text { composition } \\
\% \mathrm{~N}\end{array}$ & $\mathrm{C} / \mathrm{N}$ \\
\hline \multicolumn{8}{|l|}{ Archaeological } \\
\hline Horse (Equus ferus caballus) & Ordiogone 2 & Viluy & -21.4 & 4.9 & 42.3 & 15.1 & 2.8 \\
\hline Horse (Equus ferus caballus) & Ordiogone 1 & Viluy & -22.0 & 3.5 & 40.1 & 15.0 & 2.7 \\
\hline Horse (Equus ferus caballus) & Tungus keul 4 & Viluy & -22.1 & 4.5 & 42.6 & 15.5 & 2.7 \\
\hline Horse (Equus ferus caballus) & Oyogosse tumula & Viluy & -21.1 & 8.0 & 41.2 & 15.1 & 2.7 \\
\hline Horse (Equus ferus caballus) & Ordiogone 1 & Viluy & -21.7 & 4.2 & 42.6 & 15.7 & 2.7 \\
\hline Horse (Equus ferus caballus) & Celyysse & Viluy & -22.4 & 4.0 & 42.5 & 15.5 & 2.7 \\
\hline Horse (Equus ferus caballus) & Okhtoubout 2 & Central Yakutia & -20.6 & 6.4 & 39.3 & 14.4 & 2.7 \\
\hline Horse (Equus ferus caballus) & Bakhtakh 2 & Verkhoyansk & -22.2 & 4.9 & 42.6 & 15.6 & 2.7 \\
\hline Bovine (Bos taurus) & Isting tumula & Viluy & -20.8 & 1.6 & 42.8 & 15.5 & 2.8 \\
\hline Hare (Lepus timidus) & Dakky kuola & Viluy & -22.7 & 3.4 & 39.6 & 14.5 & 2.7 \\
\hline Carp (Carassius carassius) & Jarama & Central Yakutia & -16.1 & 11.6 & 39.5 & 15.4 & 2.6 \\
\hline \multicolumn{8}{|l|}{ Modern } \\
\hline Dog (Canis familiaris) & Ordiogone & Viluy & -20.3 & 9.5 & 38.1 & 14.0 & 2.7 \\
\hline Carp (Carassius carassius) & Nam & Central Yakutia & -29.8 & 7.5 & 38.3 & 14.1 & 2.7 \\
\hline Carp (Carassius carassius) & Kobiaï & Central Yakutia & -15.4 & 9.8 & 38.9 & 14.9 & 2.6 \\
\hline Carp (Carassius carassius) & Amga & Central Yakutia & -11.5 & 9.3 & 42.8 & 14.7 & 2.9 \\
\hline Dace (Leuciscus leuciscus) & Pokrovsk & Central Yakutia & -27.2 & 8.0 & 44.4 & 14.7 & 3.0 \\
\hline Dace (Leuciscus leuciscus) & Pokrovsk & Central Yakutia & -26.6 & 7.9 & 44.4 & 14.8 & 3.0 \\
\hline Dace (Leuciscus leuciscus) & Pokrovsk & Central Yakutia & -24.3 & 9.1 & 37.3 & 13.9 & 2.7 \\
\hline Pike (Esox lucius) & Nam & Central Yakutia & -25.6 & 7.9 & 42.9 & 14.1 & 3.0 \\
\hline
\end{tabular}




\begin{tabular}{|c|c|c|c|c|c|c|c|c|c|}
\hline Site & $N$ of burial & Region & Sex & Social status & $\delta^{13} \mathrm{C}$ & $\delta^{15} \mathrm{~N}$ & \begin{tabular}{|c|}
$\begin{array}{c}\text { Elemental } \\
\text { composition } \\
\% \mathrm{c}\end{array}$ \\
\end{tabular} & $\begin{array}{c}\text { Elemental } \\
\text { composition } \\
\% \mathrm{~N}\end{array}$ & $\mathrm{c} / \mathrm{N}$ \\
\hline \multicolumn{10}{|c|}{ Phase 1 : Before 1700} \\
\hline Boyola & 1 & Central Yakutia & 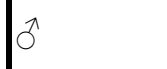 & |• & -20.8 & 9.5 & 41.5 & 15.1 & 2.7 \\
\hline Djoussoulen & 1 & Central Yakutia & 2 & •• & -20.6 & 9.9 & 39.5 & 14.3 & 2.8 \\
\hline At daban & 4 & Central Yakutia & $\theta^{2}$ & 0 & -19.1 & 10.4 & 42.3 & 15.6 & 2.7 \\
\hline Oulakh & 2 & Central Yakutia & 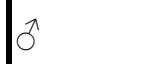 & - & -20.0 & 10.7 & 40.9 & 15.1 & 2.7 \\
\hline Tyyt bappyt & 1 & Central Yakutia & $\theta^{2}$ & 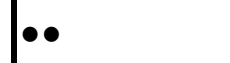 & -20.4 & 10.9 & 41.1 & 15.0 & 2.7 \\
\hline Bouogaryma & 1 & Central Yakutia & 2 & o & -20.3 & 11.2 & 42.8 & 15.5 & 2.8 \\
\hline Lampa & 1 & Central Yakutia & $\theta^{2}$ & - & -20.2 & 12.1 & 40.5 & 14.6 & 2.8 \\
\hline Taralai & 1 & Central Yakutia & $\theta^{2}$ & - & -19.5 & 12.7 & 43.3 & 15.7 & 2.7 \\
\hline Kureleekh & 1 & \begin{tabular}{|l}
$\begin{array}{l}\text { North } \\
\text { (Verkhoyansk) }\end{array}$ \\
\end{tabular} & 2 & $\bullet \bullet$ & -20.1 & 9.8 & 36.8 & 13.4 & 2.7 \\
\hline Tungus keul & 5 & Viluy & $\pi$ & 0 & -21.3 & 11.6 & 37.7 & 13.8 & 2.7 \\
\hline Oyogosse tumula & 1 & Viluy & $\pi$ & $\bullet$ & -18.8 & 11.8 & 40.1 & 14.7 & 2.7 \\
\hline Tympy & 1 & Viluy & $\hat{3}$ & $\bullet$ & -20.0 & 12.9 & 43.2 & 15.8 & 2.7 \\
\hline \multicolumn{10}{|l|}{ Phase $2: 1700-1750$} \\
\hline Istekh myran & 2 & Central Yakutia & q & - & -20.8 & 10.0 & 40.8 & 14.9 & 2.7 \\
\hline At daban & 8 & Central Yakutia & if & - & -19.8 & 10.4 & 41.7 & 15.4 & 2.7 \\
\hline Boyola & 2 & Central Yakutia & q & o & -20.5 & 10.4 & 28.8 & 10.3 & 2.8 \\
\hline Odjulun & 2 & Central Yakutia & q & |•• & -20.4 & 10.7 & 41.9 & 15.4 & 2.7 \\
\hline At daban & 6 & Central Yakutia & q & |•• & -20.2 & 10.8 & 40.7 & 15.1 & 2.7 \\
\hline Okhtoubout & 2 & Central Yakutia & q & - & -20.5 & 11.2 & 34.1 & 12.4 & 2.7 \\
\hline Tchotchour & 1 & Central Yakutia & q & - & -19.9 & 11.2 & 40.2 & 14.8 & 2.7 \\
\hline Eletchei & 1 & Central Yakutia & q & |•• & -20.5 & 11.3 & 41.6 & 15.1 & 2.7 \\
\hline Bere & 1 & Central Yakutia & q & $\bullet$ & -20.5 & 11.3 & 44.6 & 16.1 & 2.8 \\
\hline Istekh myran & 1 & Central Yakutia & q & 0 & -20.6 & 11.4 & 37.6 & 13.7 & 2.7 \\
\hline Arbre chamanique & 1.2 & Central Yakutia & q & ••• & -20.4 & 11.6 & 30.1 & 10.9 & 2.8 \\
\hline Sordonokh & 1 & \begin{tabular}{|l|}
$\begin{array}{l}\text { North } \\
\text { (Verkhoyansk) }\end{array}$ \\
\end{tabular} & qo & $\bullet \bullet$ & -20.6 & 9.8 & 40.2 & 14.6 & 2.7 \\
\hline Kureleekh & 2 & \begin{tabular}{|l} 
North \\
(Verkhoyansk)
\end{tabular} & q & |• & -20.9 & 10.1 & 35.1 & 12.2 & 2.9 \\
\hline Tysarastaakh & 2 & $\begin{array}{l}\text { North } \\
\text { (Verkhovansk) }\end{array}$ & q & $\bullet \bullet$ & -20.4 & 10.2 & 35.6 & 12.9 & 2.7 \\
\hline Boulgounniakh & 2 & Viluy & 9 & $\bullet$ & -20.0 & 10.9 & 36.6 & 13.4 & 2.7 \\
\hline At daban & 7 & Central Yakutia & 3 & - & -21.9 & 4.4 & 40.7 & 15.1 & 2.7 \\
\hline Sytygane sihe & 2 & Central Yakutia & $\hat{0}^{2}$ & |•• & -22.0 & 4.9 & 41.7 & 15.4 & 2.7 \\
\hline Sytygane sihe & 1 & Central Yakutia & 3 & 0 & -20.4 & 10.3 & 42.5 & 15.5 & 2.7 \\
\hline Sytygane sihe & 3 & Central Yakutia & 3 & 0 & -20.6 & 10.4 & 42.6 & 15.3 & 2.8 \\
\hline Oktiom & 1.1 & Central Yakutia & $\hat{3}^{2}$ & •• & -20.3 & 10.4 & 41.1 & 15.1 & 2.7 \\
\hline Oulakh & 5 & Central Yakutia & $3^{2}$ & |•• & -20.2 & 10.7 & 41.0 & 15.1 & 2.7 \\
\hline Kous tcharbyt & 1 & Central Yakutia & $\hat{0}^{2}$ & ..• & -20.5 & 10.8 & 42.2 & 15.4 & 2.7 \\
\hline Oulakh & 4 & Central Yakutia & $\hat{\alpha}^{2}$ & •• & -20.1 & 11.0 & 40.1 & 14.7 & 2.7 \\
\hline Sette toumoul & 1 & Central Yakutia & 8 & |• & -20.2 & 11.3 & 42.6 & 15.5 & 2.7 \\
\hline Urun myran & 1 & Central Yakutia & $\hat{\theta}^{2}$ & .•. & -20.4 & 11.7 & 42.6 & 15.5 & 2.7 \\
\hline Oulakhan alaas & 1 & Central Yakutia & 2 & $\bullet \bullet$ & -20.5 & 11.7 & 58.4 & 21.4 & 2.7 \\
\hline Sola & 2 & Central Yakutia & $\hat{3}^{2}$ & $\bullet$ & -20.4 & 11.9 & 35.5 & 13.1 & 2.7 \\
\hline Atyyr meite & 1 & \begin{tabular}{|l} 
North \\
(Verkhoyansk)
\end{tabular} & 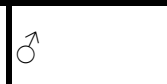 & |•• & -20.8 & 9.6 & 36.1 & 13.1 & 2.7 \\
\hline Kerdugen & 1 & $\begin{array}{l}\text { North } \\
\text { (Verkhovansk) }\end{array}$ & 3 & •• & -21.1 & 9.7 & 39.7 & 14.5 & 2.7 \\
\hline Bakhtakh & 3 & $\begin{array}{l}\text { North } \\
\text { (Verkhoyansk) }\end{array}$ & 3 & |•• & -20.8 & 9.8 & 42.9 & 15.8 & 2.7 \\
\hline Alyy & 1 & $\begin{array}{l}\begin{array}{l}\text { North } \\
\text { (Verkhoyansk) }\end{array} \\
\end{array}$ & $\hat{2}$ & $\bullet \bullet$ & -20.9 & 10.6 & 43.9 & 15.9 & 2.8 \\
\hline Boulgounniakh & 1 & Viluy & $a^{2}$ & 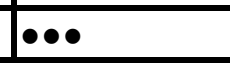 & -20.3 & 10.4 & 39.0 & 14.2 & 2.7 \\
\hline \begin{tabular}{|l|l} 
Atakh \\
\end{tabular} & 1 & Viluy & $a^{2}$ & o & -18.7 & 11.2 & 41.8 & 15.2 & 2.7 \\
\hline Ordiogone & 1 & Viluy & $\hat{0}^{2}$ & $\bullet \bullet$ & -20.5 & 11.2 & 43.9 & 15.5 & 2.8 \\
\hline Célyssé & 1 & Viluy & $0^{2}$ & $\bullet$ & -20.0 & 12.6 & 32.8 & 11.9 & 2.7 \\
\hline \multicolumn{10}{|l|}{ Phase $3: 1750-1800$} \\
\hline Us sergué & 1 & Central Yakutia & q & 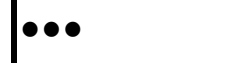 & -20.5 & 10.8 & 41.4 & 15.2 & 2.7 \\
\hline Lepsei & 2 & $\begin{array}{l}\text { North } \\
\text { (Verkhovansk }\end{array}$ & iq & o & -20.7 & 9.4 & 41.4 & 15.2 & 2.7 \\
\hline Lepsei & 1 & $\begin{array}{l}\text { North } \\
\text { (Verkhoyansk) }\end{array}$ & + & 0 & -20.8 & 9.9 & 43.2 & 15.8 & 2.7 \\
\hline \begin{tabular}{|l|l} 
Isting tumula \\
\end{tabular} & 1 & Viluy & क & $\bullet$ & -20.0 & 12.8 & 40.1 & 14.6 & 2.7 \\
\hline Bekh alaas & 4 & Central Yakutia & $\theta^{2}$ & o & -20.3 & 11.3 & 35.2 & 12.8 & 2.7 \\
\hline Tomtor & 1 & \begin{tabular}{|l}
$\begin{array}{l}\text { North } \\
\text { (Oymiakon) }\end{array}$ \\
\end{tabular} & $\hat{x}$ & 0 & -20.7 & 10.8 & 39.2 & 14.0 & 2.8 \\
\hline Kouranakh & 1 & $\begin{array}{l}\begin{array}{l}\text { North } \\
\text { (Verkhoyansk) }\end{array} \\
\end{array}$ & $\hat{\theta}$ & - & -20.5 & 9.3 & 40.4 & 14.8 & 2.7 \\
\hline Buguyekh & 3 & \begin{tabular}{|l}
$\begin{array}{l}\text { North } \\
\text { (Verkhoyansk) }\end{array}$ \\
\end{tabular} & 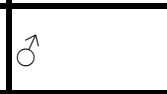 & - & -20.9 & 10.3 & 42.4 & 15.5 & 2.7 \\
\hline Ordiogone & 2 & Viluy & is & $\bullet$ & -21.1 & 5.3 & 43.5 & 16.0 & 2.7 \\
\hline \multicolumn{10}{|l|}{ Phase 4 : After 1800} \\
\hline At daban & 9 & Central Yakutia & q & - & -20.5 & 11.4 & 40.9 & 15.0 & 2.7 \\
\hline Tomtor & 2 & $\begin{array}{l}\begin{array}{l}\text { North } \\
\text { (Oymiakon) }\end{array} \\
\end{array}$ & 8 & o & -20.3 & 9.5 & 35.9 & 13.1 & 2.7 \\
\hline Balaganakh & 3 & $\begin{array}{l}\begin{array}{l}\text { North } \\
\text { (Oymiakon) }\end{array} \\
\end{array}$ & $\hat{2}$ & o & -20.4 & 10.9 & 40.3 & 14.7 & 2.7 \\
\hline Ken ebe & 8 & Central Yakutia & q & 0 & -20.9 & 10.4 & 42.7 & 15.6 & 2.7 \\
\hline Toutekh & 1 & Central Yakutia & $\sigma^{2}$ & 0 & -20.7 & 11.9 & 32.1 & 11.6 & 2.8 \\
\hline
\end{tabular}


rtefacts). 